Rok XIV (2019) | 2 (28) | s. 165-180

https://doi.org/10.12797/LV.14.2019.28.11

Stanisława Niebrzegowska-Bartmińska (0)

Uniwersytet Marii Curie-Skłodowskiej, Lublin

stanislawa.niebrzegowska-bartminska@poczta.umcs.lublin.pl

\title{
A CZY TO JA KALIKA, CZY NIE MOM KONIKA? (NIE)SPRAWNOŚĆ W ŚWIETLE EROTYKU LUDOWEGO
}

Słowa klucze: erotyk ludowy, pieśń miłosna, wartości, miłość, niepełnosprawność, kosmos Keywords: folk erotic poetry, love song, values, love, disability, cosmos

Seksualność człowieka i wszelkie jej przejawy nie stanowią samoistnego, wyizolowanego wycinka kultury, łatwo poddającego się rozpoznaniu i opisowi. Pozostają one niezmiennie w ścisłym, funkcjonalnym związku z całym szeregiem zjawisk kulturowych, których wnikliwy badacz nie powinien pomijać, jeśli chce dotrzeć do istoty tego aspektu ludzkiego życia

- pisze w książce Miłość ludowa. Wzory miłości wieśniaczej w polskiej pieśni ludowej XVIII-XX wieku Dobrosława Wężowicz-Ziółkowska (1991: 17). Do zjawisk tych należą m.in. role przypisane mężczyźnie i kobiecie, koncepcja małżeństwa i rodziny, obowiązujące we wspólnocie normy moralne i obyczajowe, funkcjonujące w kontekście aksjosfery społeczności ludowej.

Gatunkiem, który zdaje sprawę z owych uwarunkowań kulturowych, aksjologicznych i normatywnych, odwołuje się przy tym do sfery ludzkiej cielesności, płciowości i seksualności (ciała, jego części i funkcji tych części), jest erotyk ludowy. Za Janiną Szymańską można stwierdzić, że folklor miłosny jest swoistą „poetycką wykładnią norm, reguł, wzorów zachowań i obyczajności kultury uczuć" (Szymańska 1997: 122). 
Erotyk jako wyrazisty gatunek wypowiedzi należy do pieśni powszechnych, autonomicznych, więc luźno powiązanych z sytuacją wykonawczą ${ }^{1}$, a te - nieograniczone do czasu i miejsca czy osoby, możliwe do wykonania przez każdego, zawsze i wszędzie (Bystroń 1924: 32) - były śpiewane np. podczas wieczornych spotkań „młodzieży zimą, przy kądzieli lub innym domowym zajęciu, latem, w czasie świątecznych majówek, a także przy pracy w polu, zwłaszcza przy pieleniu, wreszcie na pastwisku, szczególnie sprzyjającym nastrojom lirycznym” (Czernik 1962: 257).

Obserwacje Jana Stanisława Bystronia i Stanisława Czernika potwierdziła Katarzyna Prorok, która na podstawie bogatego korpusu erotyków opublikowanych w monografii Lubelskie (BartPANLub) w syntetyzującym artykule pt. Gorzała lipka i jawor - lubelskie erotyki ludowe (Prorok 2014) dokonała opisu dziewięciu konstytutywnych wyznaczników pieśni miłosnej² ${ }^{2}$ Idąc jej tropem, można przyjąć, że erotyk jest gatunkiem ustnym, lirycznym, typem tekstu, w którym najczęściej dialogują (lub wypowiadają się) pieśniowi kochankowie - On i Ona (Jasio i Kasia). Wewnętrznym celem wpisanym w teksty gatunku (intencją) są zaloty i wyznanie/wyrażenie miłości (szczególnie tej zmysłowej) za pomocą szczegółowych aktów mowy: pytań o wzajemność/wierność, powitań, pożegnań, złorzeczeń, nakazów, apeli o ożenek, miłość, o zaprzestanie/rozpoczęcie umizgów, pochwał, złości i irytacji. Erotyk nie ma obowiązkowej fabuły, jest gatunkiem lirycznym z podstawowym tematem, jakim jest miłość. Z tego względu Jerzy Bartmiński (1981: 22-23) nazwał go „wielką pieśnią o miłości”. Teksty pieśni ujawniają historię miłosnych „akcji” - od pierwszego spotkania, przez umizgi, zaloty, schadzki, wyznania i obietnice, igraszki i swa-

1 W systematyce gatunków polskiego folkloru, wyłożonej przez Jerzego Bartmińskiego w książce Folklor - język - poetyka (1990), uwikłanie tekstu w sytuację zostało wyodrębnione jako pierwszy parametr w opisie. Pozostałe to: 2) rodzaj sytuacji, 3) konkretne jakości tych sytuacji, 4) obowiązkowa obecność fabuły dramatycznej lub epickiej przeciwstawiona brakowi lub fakultatywności takiej fabuły, 5) przekaz w formie mówionej lub śpiewanej, czyli brak lub obecność kodu muzycznego, 6) przekaz z wykorzystaniem lub bez wykorzystania gestów, czyli obecność lub brak kodu somatycznego, 7) forma wierszowana lub prozatorska tekstów, 8) intencje wewnętrzne przekazu, 9) prawdziwość lub fikcyjność treści, czyli odniesienie do świata realnego lub wyobrażonego, 10) poetyka, 11) temat (ibid.: 21-23).

2 Katarzyna Prorok uwzględniła w opisie parametry wyodrębnione dla opisu gatunku przez J. Bartmińskiego i Stanisławę Niebrzegowską-Bartmińską w podręczniku akademickim Tekstologia (2009) oraz przez S. Niebrzegowską-Bartmińską w tekście Miejsce wartości w opisie gatunków mowy (2012). Pierwsze osiem parametrów to: 1) nadawca, 2) odbiorca, 3) sytuacja komunikacyjna, tj. okoliczności, czas i miejsce, 4) intencja komunikacyjna (wewnętrzny cel), 5) temat (przedmiot), 6) ontologia świata przedstawionego, tj. fikcjonalność lub realność, 7) forma (ustna lub pisemna), 8) sposób ujęcia, czyli poetyka (Bartmiński, Niebrzegowska-Bartmińska 2009: 145-146), parametr dziewiąty to wartości (komponent aksjologiczny) (Niebrzegowska-Bartmińska 2012: 34 i nast.). Poza nimi elementem wyodrębniającym się np. w definicjach słownikowych jest wstępna kategoryzacja („genus proximum”), ta jednak bywa dokonywana na różnych poziomach. Autorzy Tekstologii, ustalając parametry w opisie gatunku mowy, odwołali się do konotacji czasownika mówić i do definicji słownikowych kilkudziesięciu nazw gatunków. 
wole, miłosne uniesienia, zdrady i skargi, żale i przestrogi, po rozstania i przeszkody lub obietnice małżeństwa ${ }^{3}$.

Jedną z ważniejszych cech erotyku jako gatunku jest przedstawienie bohaterów, ich atrybutów i zdarzeń z użyciem kodu paraleliczno-symbolicznego. Zastosowana w pieśniach ludowych „technika budowania większych konstrukcji znakowych i kształtowania ich znaczeń", by użyć formuły J. Bartmińskiego (1993: 219), polega na równoległości, odpowiedniości i zestawieniu ze sobą - na zasadzie opisowej, logicznej, niekiedy też formalnej - dwóch obrazów: jednego ze świata przyrody (zwykle roślin i zwierząt), drugiego ze świata ludzi (więcej o tym zob. Moszyński 1939: 1392)4. W pieśniach dokonuje się tego w taki sposób, że „opisując działanie ludzkie, równocześnie opisuje [się] zjawiska świata zewnętrznego, sprawiając niejednokrotnie wrażenie, jak gdyby były one ze sobą w jakimś istotnym, choć bliżej nie dającym się określić związku" (Bystroń 1921: 174; por. SFPKrz: 293).

Paralelizm jest semantyczną odmianą powtórzenia, przekazującą istnienie podobieństwa (w pierwotnej postaci może nawet identyczności) przy pozorach inności. Jego filozoficzną podbudową jest animizm, tj. wiara w jedność życia w Kosmosie i odczucie mistycznej więzi człowieka z całym otaczającym go światem przyrody

- konstatuje J. Bartmiński (1993: 219), charakteryzując środki poetyckie (powtórzenie, paralelizm i symbol) charakterystyczne dla ludowego stylu artystycznego.

Symbol jako „zredukowany paralelizm” czytelny jest dopiero na tle całej kultury i funkcjonującej w jej ramach sieci kodów i symboli. Tak np. w pieśniach miłosnych: Nie ścinaj kaliny, bo jej nie zetnies, Nie kochaj dziewczyny, bo jej nie weźmies (BartPANLub IV: 153 Szyszki, gm. Stoczek Łukowski); Świyci miesiąc, świyci miyndzý gwiázdeckami, Nájładniejsáś, Rózuś, miyndzý kobiytami (RakPodh: 71 Chochołów) - kalina i gwiazda są symbolami dziewczyny; w pieśniach weselnych: Zakukała kukowecka na ługu, zabiroj sie, moja Marysieńko, do ślubu. Zakukała kukowecka na dworze, zapłakała moja Marysieńka w Kumorze (BartPANLub II: 104 Niezdów, gm. Opole Lub.); Oj, kołem, kołem, kołem jasne słoneczko schodzi, nasza Marysia, nasza nadobna do ślubu już odchodzi (ibid.: 133 Przypisówka gm. Firlej) - kukaweczka i słońce przyjmują sensy naddane i stają się „zastępnikami” panny młodej ${ }^{5}$.

W erotyku ludowym, pojmowanym jako ,śpiew kochanków niezwiązanych jeszcze węzłem małżeńskim” (Bartmiński 1974: 178), miłość jest ukazywana w sposób

3 W takie działy układał teksty pieśni miłosnych Oskar Kolberg w Ludzie. Taki też układ dla erotyków przyjęli: w Lubelskiem K. Prorok (zob. BartPANLub IV: 128-599), a w Materiałach do etnografii Podhala Maciej Rak (zob. RakPodh: 63-116).

4 Kazimierz Moszyński podkreślał, że zjawisko paralelizmu charakterystyczne jest w szczególności dla Słowian wschodnich, rzadziej występuje u Słowian zachodnich, a u Słowian południowych jest nieobecne (Moszyński 1939: 1392-1393).

5 Więcej na temat ustalania znaczeń symbolicznych zob. Niebrzegowska-Bartmińska 2013. Bogactwo takich sensów przynosi lubelski Słownik stereotypów i symboli ludowych (SSiSL). 
dynamiczny, z równowagą pierwiastków psychicznych i zmysłowych oraz z demokratyzacją ról kobiecych i męskich (ibid.: 16). Przedstawieniu miłości w „kalinowym lesie” pomaga rekwizyt, który bywa „zastępnikiem” kochanków i ich ciała. Znamienne dla erotyku jest funkcjonowanie w nim specjalnego kodu symbolicznego, w którym narządy płciowe męskie i kobiece kojarzone są z obrazem zwierząt i ptaków (ofiary i jej antagonisty), obiektów fizjograficznych i narzędzi pomocnych w ich uprawie, narzędzi i urządzeń gospodarskich, sprzętów domowych czy instrumentów muzycznych i ich użytkowników. Tak więc ziemia, łączka, piec, fartuch, gniazdko, kura, niecka czy dzieża funkcjonują w tekstach erotyku jako symbole żeńskie, a pług, radło, kosa, kominiarz, grzyb, żoładź, ptaszek, kogucik, klin czy młotekjako symbole męskie. Pokazali to w swoich studiach badacze ludowej miłości (ibid., a w nawiązaniu do jego ustaleń też: Wężowicz-Ziółkowska 1991; Prorok 2014).

Symbole

\begin{tabular}{ll}
\hline \multicolumn{1}{c}{ ŻEŃSKIE } & pług, radło, oracz \\
\hline rola, pole, bruzda & ziarno, siewca \\
\hline ziemia & kosa, grabie, kosiarz \\
\hline łąka & cepy, bijak, młockarz \\
\hline gumno & konik \\
\hline żłób, poidło & wrzeciono \\
\hline krosno, kądziel & stęporek \\
\hline stępa & klin, młotek, bednarz \\
\hline niecka, dzieża, faska, szkopiec & kowal, młot \\
\hline kowadło & kominiarz, murarz \\
\hline komin, piec & grzyb, żołąd́ \\
\hline fartuch, koszyk, zapaska & kiełbaska \\
\hline garnek, kuchenka & smyk, piszczałka, dudarz, instrumencik \\
\hline dudy, bandurka, skrzypce & kot \\
\hline mysz & kozioł, wilk \\
\hline koza & ptaszek \\
\hline gniazdko & jastrząb, kogucik, kurasek \\
\hline kokoszka, kura & gawron \\
\hline kawka & klucz \\
\hline zamek & leśniczy \\
\hline las & pióro, ołówek \\
\hline kałamarz & \\
\hline
\end{tabular}

Tabela za: Wężowicz-Ziółkowska 1991: 161. 
W świetle przywołanych zestawień można zauważyć, że symbolizm seksualny w pieśni ludowej odpowiada teorii Zygmunta Freuda (1987) i wykładniom marzeń sennych $^{6}$, w których ludzka podświadomość uwalnia się od skrępowania obyczajowego, norm moralnych i schematów kulturowych. Podobnie jak w snach, tak i w erotyku ludowym przedmioty ostre, wydłużone, zdolne do uderzania, zagłębiania, przesuwania kojarzone są z narządami płciowymi męskimi, a przedmioty (naczynia) okrągłe, posiadające wgłębienia i otwory, zdolne do zawierania, przyjmowania czegoś do swego wnętrza - z narządami płciowymi żeńskimi. Zwierzęta drapieżne przeciwstawiane są ich ofiarom, samce - samiczkom, wykonawcy czynności - obiektom, na które mogą oddziaływać (por. Bartmiński 1974: 180-181).

Te właściwości obu szeregów symbolicznych wydają się jednocześnie stanowić podstawę relacji między symbolizującym a symbolizowanym, podstawę paralelizmu kobieta - ziemia, vagina - bruzda, cunnus - bandurka, mężczyzna - oracz etc. (Wężowicz-Ziółkowska 1991: 162).

Symbole proste w tekstach erotyku wchodzą w złożone układy kombinatoryczne i funkcjonują jako makroznaki. Na przykład łączka zielona z trawka niepokoszoną lub bijące i czyste źródło to symboliczne przedstawienie czystości panny, dawanie listeczków lelijeczki - oddawanie się przez dziewczynę chłopcu, usychanie lelijeczki, spadanie kwiatka z róży/leliji - znak utraty dziewictwa:

(1) Mam-ci ja też Jasiu łączkę zieloną, na niéj traweczkę niepokoszoną. Tylko koszenia potrzeba, da nam Pan Bóg wszystko z nieba, dobrze nam będzie (K 21 Rad: 39 Końskie).

(2) Panno Marysiu, daj lelije! Nie dam, nie dam ni kwiateczka, bo mi zeschnie lelijeczka, hej, kolęda, kolęda! (KotRzesz: 227 Dachnów).

(3) Daj mi, Zosiu, z tej leliji choćby jeden listeczek, ażeby o tym nie wiedział twój miły kochaneczek (ibid.: 133-134 Grząska).

(4) O Boze, Boze, spad(ł) mi kwiatek z róze, spadła i leluja, zmiéniła się i ja (K 44 Gór: 409 „od Krościenka”, Czorsztyn).

W ludowych pieśniach miłosnych i zalotnych obrazy złożone mają zwykle charakter zdarzeniowy i oddają dynamikę aktów miłosnych, fluktuacji uczuć, uniesień, spotkań i rozstań, zbliżeń i zdrad pieśniowych kochanków. Prawidłowością jest to, że znaczeń naddanych w pieśniach nabierają proste czynności rolnicze: oranie, sianie, bronowanie, koszenie, zjawiska meteorologiczne i pogodowe: słońce, rosa, deszcz, woda. Obrazy orania roli, pojenia konia, pasienia pawia, wpadania $w$ rzeczke, moczenia spódniczki, roszenia trzewiczków, padania deszczu/rosy na brzezinę / kalinę I leszczynę / sadek wiśniowy w pieśniach ludowych przyjmują sensy dodatkowe i dają

6 W odniesieniu do polskiego sennika ludowego opisała je S. Niebrzegowska (1996). 
się wykładać w kategoriach aktu płciowego, miłosnych zbliżeń kochanków, oddawania się dziewczyny chłopcu oraz utraty dziewictwa:

(5) W stodole świta, w rogu dzień, posła dziewczyna po ogień. Nie po ogień chodziła, tylko Jasia budziła, budziła. Wstońże, Jasieńku - nie lez-ze, idź do roleńki - podorz-ze. Idę, dziewcyno - nie wołaj, juz ja roleńkę - podorał (K 27 Maz: 239 Złotowo pod Szreńskiem).

(6) Jakże ja mam wstać, koniom wody dać, zimna, zimna rosa, a ja bosa, nie mogę wytrwać (BartPANLub III: 316 Zemborzyce, gm. Konopnica).

(7) Z tamtej strony - zielonego stawka pasła panna prześlicnego pawia. Trąciła-ć go w ogonek niechcący, paw poleciał do boru krzycący. Ona za nim i go wołający, wpadła w rzyczkę, zmacała spódnickę (K 28 Maz: 242 od Grajewa, Rajgrodu).

(8) Przyjechał do nij kawaler młody: chodźwa, dziewcyno, w gęste jagody. Ja tam nie pójdę, bo zimna rosa. Chodźwa, dziewcyno, to cię przeniosę. Ej, co jej, co jej? dziewcynie mojej, straciła wianek, chodząc po roli (K 26 Maz: 215 od Siennicy).

(9) Prosze ja cie, prosze, nie prowadź mnie w rose, bo ja młodziusieńka, trzewiczki zarosze (TN Strupin Duży 1966).

(10) Deszczyk pada, rosa siada po drobnej leszczynie, zalecaj się, namilejszy, ale nie zdradliwie (GąsMazur: 137).

U podłoża erotyku ludowego, podobnie jak u podstaw każdego gatunku, zgodnie z tezą Stanisławy Niebrzegowskiej-Bartmińskiej (2012, 2015), leżą wa r tości ważne dla nosiciela kultury ludowej, relatywizowane ze względu na typ subiektu. Jest to podmiot, o którym mowa w tekście (poziom przedstawieniowy) i/lub do którego tekst jest adresowany (poziom interakcyjny). W przypadku pieśni miłosnych bohaterami są ludzie młodzi, najczęściej kochankowie niepołączeni jeszcze ślubem. Wartościami nadrzędnymi (akcentowała to w swoim szkicu Katarzyna Prorok), które w erotyku ludowym ogniskują inne, są miłość i szczęście w miłości. Wartości „stowarzyszone”, powiązane z nimi sieciowo to m.in.: kontakt fizyczny, otwartość kochanków na prowadzoną grę miłosną, młodość i piękno, powodzenie i przychylność, beztroska zakochanych, dobra zabawa i śmiech, wolność, wierność i stałość, bogactwo; wartością względną jest bogactwo i małżeństwo (jest to wartość istotna dla dziewczyny) (Prorok 2014).

Rejestr ten - w moim przekonaniu - należy uzupełnić o sprawność seksualną ${ }^{7}$. Argumentów za wysokim wartościowaniem tej właściwości ciała kochanków i jej roli w akcie miłosnym (w „kochaniu”) dostarcza już etymologia słowa kochać, któ-

7 Wartość ta pozostaje w związku z „kontaktem fizycznym” wyróżnionym wśród wartości przez K. Prorok. 
ra wiąże kochanie z fizycznością, z dotykaniem i poruszaniem. Sprawność seksualna to zatem zdolność i umiejętność „dotykania, poruszania”. Związek kochania $z$ dotykiem eksponowała (w nawiązaniu do ustaleń Franciszka Sławskiego) Urszula Majer-Baranowska (1980: 83), autorka hasła kochać w Zeszycie próbnym Słownika ludowych stereotypów językowych (SLSJ). Dziś hipotezę F. Sławskiego potwierdza też Wiesław Boryś, który pisze:

psł. dial. ${ }^{\star} k o c h a t i$, prawdopodobnie ekspresywny wariant psł. ${ }^{\star} k o s a t i$ 'dotykać, poruszać, ${ }^{*} k o s n q t i$ 'dotknąć, poruszyć' [...]. Pierwotne znaczenie zapewne 'lekko, delikatnie dotykać, głaskać', stąd 'pieścić' (> 'całować, obejmować ramionami, ściskać), 'dogadzać komuś i dalej 'pielęgnować, hodować, powodować rozwój, wzrost' i 'sprawiać komuś przyjemność, radować kogoś, okazywać przychylne uczucia, miłować (SEBor: 241).

Sprawne ciało to element niezwykle ważny, można powiedzieć kluczowy w akcie miłosnego zbliżenia, nie dziwi zatem fakt, że w pieśni miłosnej zalety ciała, jego budowę, właściwości, dynamizm i energetyczność chwalą pieśniowi bohaterowie, robi to zarówno dziewczyna, jak i chłopak:

(11) Mam ci ja, Maćku, łączeńkę drobną, traweczkę na niej, gdyby jedwabną, a pośrodku źródło bije, traweczka się pięknie wije, nigdy nie zgnije. Mam ci, Kasiu, kosisko spore, jak wezmę kosić, trawka wygore, hej pokos koło pokosa, dobrzeć kosi moja kosa, aż pierzcha rosa (ChodŚp: 193).

(12) Mam ci ja, Jasiu, swéj roli staję, na niéj się zboże bujne udaje. Tylko uprawy potrzeba, da nam Pan Bóg wszystko z nieba, dobrze nam będzie. Mam ja też, Kasiu, bydlątek troje, pójdzie jedno wprzódy, a za nim dwoje. I płużek też tam będzie, wszystko się do kupy zejdzie, dobrze nam będzie (K 21 Rad: 39 Końskie).

Dziewczyna eksponuje walory swojej bujnej roli, bo ta może wydać obfite plony, por. bujny 'obficie rozrastający się', 'żywy, nieokiełznany, bogaty' (USJP I: 344). Chłopiec chlubi się narzędziami (płużkiem) i zwierzętami (bydlątkami), bo te są niezbędne przy uprawie roli. Łączeńka niepokoszona z bijącym źródłem to obraz panny, która zachowała dziewictwo i chce swoją czystość ofiarować ukochanemu chłopcu. Sprawność seksualna pieśniowego Jasia w akcie miłosnym, w jego przebiegu i zaistnieniu jest jednak o wiele ważniejsza niż sprawność Kasi (w akcie płciowym Jaś jest agensem, a Kasia obiektem czynności) - dobrze skosić łackę może nie lada kiep; o dobrej kośbie łączki decyduje odpowiednie kosisko ${ }^{8}$. Jest to szczególnie ważne

8 W tym artykule interesuje mnie głównie sprawność chłopaka/mężczyzny, co nie znaczy, że sprawność dziewczyny/kobiety, „odpowiedniość” jej narządów płciowych względem męskich w akcie miłosnym nie jest istotna. Por. w pieśni z Lubelskiego: Bodaj cie, Zosieńku, wszystkie gromy 
zwłaszcza wtedy, gdy z łacki panny źródełecko ciece, gdy jej łączka jest "ogrodzóna, a na łączce lelija wsadzóna [= gdy panna jest dziewicą]:

(13) Moja łącka przy niskiej dolinie, można ją siec i w lecie, i w zimie [...]. Z mojej łącki źródełecko ciece, mojej łącki lada kiep nie siece (LL: 58 ).

(14) Moja łuncka wkoło "ogrodzóno, a we środek lelujo wsadzóno. Na myj łunczce rzundne zowaliska, to tam trzeba nie lada ku osiska (KrzyżWiM III: 28 Szczytno, warianty zob. ibid.: 27 Purda, Orzysz).

Narządy niesprawne, „chore”, tracą właściwe sobie funkcje - w pieśniach mowa o tym, że funkcje przypisane intymnym częściom ciała mogą ustawać czasowo (co normalne), a także gdy „niesprawność”, „chorowanie” bywa rodzajem gry miłosnej. Chore ciało wymaga leczenia, a najlepszą „lekarką" chorego narządu (wyłamanej/ wywiniętej/chorej nogi/kulasa, ognia/puchliny w kulawej nodze) jest dziewczyna, pieśniowa kochanka - to ona jest w stanie sprawić, że kulas wstaje:

(15) Skoczył z konia przez uwagi, wyłamał nogę. Moja miła pani matko, chodzić nie mogę. Nie bójze się, Kasiu, ognia ani puchliny, połozę ja chorą nogę wele pierzyny (K 2 San: 131 od Tarłowa, Lipska); warianty: Skocył z konia nieuwaznie i wywinął nogę: Moja Maryś, moja droga, juz chodzić nie mogę! Idź-ze po doktora albo idź do pana, jak mnie doktor nie ulicy (uleczy), to ulic mnie sama. Pościelze mi, moje dziéwce, moje złoto, w téj nowéj komorze i układź się ty kole mnie, toć mi to pomoze. Posłać ci się nie odrzekam, ukłaść się nie mogę, zeby ci się ogiń nie wdał w tę kulawą nogę. A nie bój-ze się, dziewcyno, nie bój-ze się ognia, będę ściskał i przytulał choć do samego dnia (K 18 Kiel: 78 Potok, podob. KrzyżKuj I: 198 Lubraniec pow. Włocławek); Oj, i spad Jasio z konika, wywinął nogę, a widzisz, ty dziewczę moje, że iść nié mogę. Poślijcie mi po doktora albo po pana. Jeśli on mnie nie uléczy, ulécz mnie sama. Wstałci kulas jak narani, nic nie upada, a widzisz, ty dziewcze moje, żeś mi pomogło (K 12 Poz: 25 od Poznania).

trzasty, żeś mi nadstawiła, żeś mi nadstawiła, hej, taki buzi ciasny. Bodaj cie, Jasieńku, piorun trzas w zapolu, jeszczem ci nie dała, jeszczem ci nie dała, jużeś sie ty pochwoluł (BartPANLub IV: 471 Bochotnica); A mam-ci ja, mam, Troje bydełecka, A u mojej kochanecki Ciasna oborecka. A bodejze to bydełko Wszystko wyzdychało, Inom-ci jedno wepchnąt, A dwoje zostało (HerKal: 58); z Krakowskiego: Dałabym ci siuśki, aleś ty maluśki, bo do mojej siuśki potrzeba metr kuśki (Wężowicz-Ziółkowska 1991: 175). Także w pieśni notowanej w XIX w. przez Wacława z Olecka, a komentowanej przez Annę Tyrpę, autorkę studium O eufemizmach w pieśniach ludowych, mowa o seksualności kobiety i jej cielesności w kontekście aktu miłosnego: „Trzy rzeczy na świecie od mężczyzny wzgardzone, rękawiczka i trzewiczek, kiedy są przestronne, a trzeciej nie powiem, bobym memi słowy obraził kobietki, a może i wdowy" (Tyrpa 2008: 245). 
Dla pieśniowej kochanki bardziej dotkliwa jest niesprawność kochanka, która łączy się z defektem „narzędzi” (kiepskie cepy), ich uszkodzeniem (rajta spadła, fajeczka się potrzaskała, kółeczko/kolcesko się połamało/złamało, bijak się skrzywił, konik okulawiat):

(16) Kazali mi cepem młócić na kosmatem gumnie, a ja im się tez wymawiał, kiepskie cepy u mnie. Jakem zacął cepem młócić, bijak mi się skrzywił, a cém-ze ja niescęśliwy bandę ludzi zywił (K 26 Maz: 333 od Żelechowa).

(17) Czyje to poleczko nie "orane, "od mego kochanka zaniedbane. "Orane, "orane, ale mało, bo mu siã koleczko połamało. Kolcesko złamało, rajfa spadła, a moja Kasinka bardzo zbladła (BielKasz II: 226 Wdzydze gm. Kościerzyna, wariant: BartPANLub IV: 252 Jacnia, gm. Adamów); Czyjeż to poleczko nie zorane, od mego miłego zaniedbane? Jest ono zaniedbane, ale mało, bo mi sã kółeczko połamało. Kółeczko mi sã połamało, fajeczka mi sã potrzaskała (BielKasz II: 226-227 Wdzydze, gm. Kościerzyna).

(18) Nie chcę tego, co mu wisi, Nieprzyjaciel moi pisi. Wolę tego, co mu stoi, Przyjaciel to pisi moi (HerKal: 55 ).

(19) Oj, myślałaś, dziewczyno, oj, że ja "o cie szalał, oj, ja se o konika, oj, bo mi okulawiał (BartPANLub IV: 551 Osowa, gm. Hańsk).

Posiadanie „narzędzi” nie przysparza kochankowi chwały, jeśli są one „niepełnowartościowe" (bo np. maluśkie), też jeśli chłopak jest nieukiem i nie ma w prawy w miłosnym rzemiośle (połamie osi, złamie dysel), jeśli krzywo orze, a piszczałka nie chce grać. Brak pełnej seksualnej aktywności naraża mężczyznę/kawalera na śmieszność i brak zainteresowania ze strony dziewczyny:

(20) Dałabyk ci siuśki, Aleś barz maluśki, A do mojej siuśki trzeba łokieć dłuśki (RakPodh: 119 Chochołów).

(21) Oja, oja! Panno moja, Niekoszona łączka twoja. Przystanę ja za kosiarza, Będę kosić raz wedle raza. - Trzeba by mi takowego kosiarza do boku mego. Wiadomego uczyć trudno, Bo on kosi łączkę równo. A z nieukiem wielka męka, Mało robi, siła stęka. Łączka [nie]koszona sto[i], A ja szkodna w łączce swojej. - On rubacha, jak wziąn kosić, Az wołała: - Już mam dosyć! - Rozmachałem kosę swoję, Postój, aż się uspokoję. - Kośże, kośże, kiedyś taki, Za każdy raz trzy szóstaki (HerKal: 40).

(22) Jasieńku, ty krzywo orzesz, czy ci wołki nie chcą chodzić, czy ty nie możesz. Kasieńko, dobrze bym orał, żebyś wołki poganiała, na zakręcie buzi dała, dobrze bym orał. Jasieńku, tyś za malutki, nie dostaniesz ucałować mojej buzieńki. Kasieńko, wezmę stołeczka ji uścisnę, ucałuję twoje usteczka (BartPANLub IV: 150-151 Bychawka, gm. Bychawa). 
(23) Oj, jechałem do Zosi, da, połamałem osi. Oj, jeśli dyszel złamię, da, to nie spojrzy na mnie (K 1 Pieś: 383 od Warszawy, wariant: HerKal: 92).

(24) $\mathrm{B}^{\mathrm{u}}$ odej zmarniała piszczałka, b odej zmarniała, zmarniała, jak jechałym do dziewczyny, grać mi niy chciała, niy chciała (KrzyżKuj: 140 Ruszki pow. Radziejów).

Ogólnie rzecz biorąc, ciało męskie pozbawione sprężystości, energii i witalności, jak również narządy płciowe zwiotczałe, niespełniające właściwych sobie, przyrodzonych funkcji są dla kochanki antywartością. Antywartością dla młodej żony jest też stary mąż, któremu ustaja siły i nie stoja wąsiska, który ma krzywy nos, nie może skakać i nie ma w kusiu kości:

(25) Niewolą mnie za starego, Niewolą, niewolą, A kiedy mu te wąsiska Nie stoją, nie stoją. A trzeba by do Warszawy Po śnury, po śnury, A stałyby te wąsiska Do góry, do góry (PrzybJabł: 398 „od Klimontowa”, Zakrzów).

(26) Co ja zrobie z takim losym, jak mam mỹża z krzywym nosem, jak go ja chce pocałować, to musze mu nos prostować (KrzyżKuj: 161 Pocierzyn, pow. Radziejów).

(27) Płakała dziewcyna, cóz ni miała płakać! Posła za starego, Co ji ni mógł skakać (Wężowicz-Ziółkowska 1991: 126 Krakowskie).

(28) Serce od załości: Nie masz w kusiu kości, Tylko same zyły, Ustają mu siły. Toć to zal prawdziwy (HerKal: 53 pieśń mazowiecka).

Mężczyzna stary (dziad / dziadzisko / stary dziad / siwobroda), zgrzybiały, niedołężny i niesprawny, ale aspirujący do ożenku (kiwa brodą, szczerzy zęby) lub żeniący się z młodą, mającą potrzeby erotyczne dziewczyną bywa przedmiotem żartów i kpin 9 . Dla panny jest odrażający - dziewczyna (niewinna jagoda) boi się dziadem zarazić:

(29) A za mąż-ci me wydają, a toć ja tam ni mom woli. Za starego, zgrzybiałego, da j-aż ci me główka boli. Siedzi stary w rokicinie, kiwa brodą ku dziewczynie. A ty stary, siwobroda, ja dziewczyna jak jagoda. Obrócił się do mnie pyskiem, da i chciał me pocałować. Wolę w grobie niż z dziadziskiem leżeć, niż dziada szanować. Oj, układ się tuż pole mnie, da i kieby piwna kłoda; a i ja téż pole (kole) niego leżę, niewinna jagoda. A zerwał my rumianeczek, da i bez wysokie ściany, a nie zerwał żagaweczki, da bo się nią bojał sparzyć. A i ja téż tak dziewula, tobą dziadu się zarazić. (K 4 Kuj: 47 „od Lubrańca”, Sułkowo;

9 Oczywiście nie zawsze starość jest kojarzona z deficytem witalności i brakiem potencji, co podpowiada np. przyśpiewka weselna z Kujaw: Mój staruszek grochowinka, pokochołby co godzinka, pokochołby co mómencik, bo mo dobry instrumyncik (StanTomKuj: 40). 
warianty zob.: K 72/1 Kuj: 271 „od Chodcza”, ibid.: 324-325 „od Kruszwicy”, Pakość).

(30) Oj, biada my, biada, żem poszła za dziada - cóż ja będę robiła? Ni ja dziada sprzedać, ni jego wytmienić [sic!], cóż ja będę robiła? Oj, biada mi i biada, a ja biedna dziewczyna! Dziad wyszczerzył zęby, woła na mnie: gęby! Jako leśna bestyjka. Oczy mu w łeb wpadły, wąsy mu opadły, broda mu osiwiała. Oj, biada mi i biada, a ja biedna dziewczyna! Żeby my się trafił jaki młody chłopiec, mile-ć bym go przyjęła. A z tym starym dziadem, widzi Bóg dalibóg, jak ja będę świat żyła? (K 4 Kuj: 54-55 „od Osięcin”, Borucin).

Niesprawność seksualna (brak znajomości miłosnego rzemiosła, „słabość”) może być nawet powodem odrzucenia kochanka przez dziewczynę i porzucenia męża przez młodą, niezaspokojoną seksualnie żonę:

(31) Żona męża odesła, bo nie umiał rzemiosła. Ani orać ni kosić, ani żonki podnosić (K 17 Lub: 45 Radecznica); wariant: Niedaleko Olesna, hop, siup Olesna, baba chłopa odeszła, hop, siup odeszła. Oj, odeszła, odeszła, hop, siup odeszła, bo nie umiał rzemiosła, hop, siup rzemiosła. Ani orać, ni kosić, hop, siup ni kosić, ni fartuszka podnosić (PłatKrak: 701-702 Dąbrowa Tarnowska).

(32) Ozenił się stary w kościele, u fary. Wyszedł na ulicę, sfajdał nogawicę. Mówiły mu panny: - Nie jedz, stary, manny, Kup-sze kasze, krupy, Boś ty słaby (HerKal: 97).

Przeciwieństwem starego męża jest młody, sprawny kochanek - tego dziewczyna akceptuje i z nim gotowa jest się związać, starego wysyła na grzyby, wsadza w miech, karmi suchą rzepa, żeby prędzy zdech (K 72/1 Kuj: 20 $)^{10}$ :

(33) Z tamtej strony wody Jest tam Antoś młody, Gdyby mi go dali, Pościłabym środy. Pościłabym środy. Pości[ł]abym piątki, Żeby mi się dostał Na Zielone Świątki (HerKal: 150).

(34) Chcą mnie wydać za starego, a ja nie mam woli, a co spojrze na młodego, to mnie serce boli (KrzyżKuj: 16o Świesz, pow. Radziejów).

(35) Nie pojde ja za starego, nie użyje nic dobrego, jak przyjdzie do spania, użyje sapania. A jak pojde za miłego, za Jasinka, za mojego, jak przyjdzie do spania, użyje kochania (ibid. Michałowo, pow. Aleksandrów).

10 W układzie przeciwnym - zestawienie starej baby i młodego kochanka - daje efekt niedopasowania podbudowanego interesownością, por. m.in. w pieśni: Zachciało się starej babie młodego gałanta, rozumiała, że on głupi, trafiła na franta. Młody gałant staréj babie skórę wyfutruje, baba lata jak szalona starości nie czuje. Powiedziałaś, stara babo, że ty masz dukaty, jak my ich tu nie pokażesz, połamię ci gnaty. Baba rada i nierada, idzie do komory, jak wynosi tak wynosi z dukatami wory (K 4 Kuj: 55 „od Włocławka, Nieszawy”). 
(36) Po cożeś się, stary dziadu, przywlók, a nie beńdzie w mojej roli twój pług, moja rola pod borem nowina, tyś stary dziad, ja młoda dziewczyna (ibid.: 259 Latkowo, pow. Radziejów).

(37) A ty stary siwy, hoc, hoc, hoc, idź z koszem na grzyby! Hoc, hoc, hoc. A ty młodziusieńki, hoc, hoc, hoc, daj my buziuleńki! hoc, hoc, hoc (K 4 Kuj: 55 „od Osięcin”, Bodzanowo bach.).

Sprawność seksualna w świetle erotyku jest dla dziewczyny / młodej żony jedną z najważniejszych wartości. Tak jak silne i sprawne ręce niezbędne były w pracy na roli i w gospodarstwie (w efekcie pomagały zapewnić byt rodzinie), tak sprawne intymne części ciała pozwalały dostarczać przyjemności kochance (sprawność erotyczna w świetle tekstów pieśni miłosnych jest więc wartością immanentną, samą w sobie) i były gwarancją przedłużenia życia, zapewnienia potomstwa (w tym wypadku sprawność seksualna jest wartością instrumentalną, służebną wobec życia jako wartości stojącej najwyżej na szczycie „drabiny aksjologicznej” wiejskiej społeczności). O ile więc niepełnosprawnośćl1 płciowa kochanka, nieumiejętność zapewnienia kochance pełnego i satysfakcjonującego zbliżenia, o których mowa w pieśniach miłosnych, naraża kawalera/mężczyznę na śmieszność ze strony kochanki, o tyle niesprawnośćc (a ta ma miejsce zwłaszcza w przypadku starego męża) zupełnie degraduje kochanka w oczach panny/kobiety.

Jak się okazuje, stopnie erotycznych „defektów” kochanka można też łączyć z obecnym we współczesnej polszczyźnie (zwłaszcza w kontekście dyskusji nad miejscem i rolą w społeczności osób niepełnosprawnych) rozpodobnieniem znaczeń wyrażeń osoba niepełnosprawna i osoba z niepełnosprawnością. Na dwie podstawowe różnice semantyczne między nimi zwracał uwagę Dariusz Galasiński w artykule Osoby niepełnosprawne czy osoby z niepełnosprawnościa?, który sygnalizował, że w wypadku określenia pierwszego (osoba niepełnosprawna) wyrażenie zamyka takie osoby w ich jednej cesze i je stygmatyzuje, wyrażenie drugie (osoba $z$ niepełnosprawnością, a nawet osoba z niepełnosprawnościami) tego zamknięcia unika, a na dodatek robi „to bez deficytu semantycznego” (Galasiński 2013: 6).

Mając na uwadze te terminologiczne rozróżnienia, w odniesieniu do erotyku ludowego warto postawić pytanie o to, czy niesprawność w miłosnym rzemiośle (nieumiejętność, niezręczność młodego kawalera, brak witalności starego męża) wpisuje pieśniowego kochanka w kategorię osób niepełnosprawnych (A) czy raczej w kategorię osób z niepełnosprawnością (B).

11 Zgodnie z definicją słownikową niepełnosprawny to tyle co 'nieosiągający pełnej sprawności fizycznej lub psychicznej wskutek ułomności lub upośledzenia umysłowego’ (USJP II: 1145).

12 Niesprawny - a) mający ograniczoną zdolność poruszania się lub pracy z powodu choroby, ułomności itp., b) o częściach ciała: niespełniający właściwie swoich funkcji; chory, uszkodzony, c) niemający sprawności, zręczności w ruchach, w wykonywaniu czegoś, d) świadczący o braku sprawności, zręczności, będący tego przejawem, e) niewłaściwie, źle zorganizowany, urządzony (USJP II: 1171). 
Przy założeniu, że niesprawność seksualna jest „niepełnosprawnością pewnego zakresu”, zdawałoby się, że ten rodzaj defektu można traktować jako częściową ułomność, częściowe kalectwo (inne „sprawności” ciała, np. zdolność do pracy w gospodarstwie, na roli są zachowane) i zaliczać niepełnosprawnego kochanka do kategorii osób z niepetnosprawnością. Jednakże, a dowodem na to są liczne teksty pieśni miłosnych, niesprawność w miłosnym rzemiośle, nieumiejętność lub niemożność odbycia przez mężczyznę aktu płciowego to dla kochanki, oczekującej miłosnego spełnienia, nie tylko „niezręczność”, „nieumiejętność”, ale to rodzaj takiej ułomności (nawet upośledzenia), która deprecjonuje i dyskwalifikuje go jako mężczyznę i partnera aktu miłosnego. Przy takim traktowaniu pieśniowy kochanek jest dla dziewczyny/kobiety osoba niepetnosprawną. Zaliczenie go do takiej kategorii zdaje się potwierdzać w pieśni sam chłopak, który w pieśni miłosnej pyta: A czy to ja kaléka, czy to ni mom konika? ${ }^{13}$

Kochanek, który ma urodę, wąsik ${ }^{14}$, konika (por. koń, konik 'fallus') nie jest niepełnosprawny, ułomny, nieudolny, niedołężny i upośledzony, nie jest kaleką - wszak kaleka (z ukr. kalíka 'kaleka', przez medium błrus. kaléka, przejęte z tur. kalık 'niedostateczny, brakujący, mający jakiś defekt, ułomny', zob. SEBor: 220) wedle współczesnej definicji słownikowej to: 1. 'człowiek dotknięty kalectwem, ułomny; inwalida', 'osoba niezaradna, niepraktyczna, nieumiejąca poradzić sobie w życiu'; 2. pot. lekcew. 'o kimś niezgrabnym, niezręcznym, łamaga' (USJP II: 220). Porównaj też: kaleki - 1. 'dotknięty kalectwem; ułomny, niedołężny, upośledzony' (kalecy ludzie, kalekie dziecko, kalekie nogi, ręce); 2. przen.: a) niedoskonały, mający usterki; niezaradny, nieudolny' (kaleki opis czegoś); b) 'uszkodzony, zniszczony' (kalekie drzewa, rzeźby) (ibid.) oraz kalectwo jako 'niedorozwój, brak lub nieodwracalne uszkodzenie narządu albo części ciała utrudniające lub uniemożliwiające normalne funkcjonowanie organizmu; ułomność, por. kalectwo wrodzone, ulec kalectwu; kalectwo życiowe 'nieumiejętność radzenia sobie w życiu, brak zmysłu praktycznego' (ibid.: 219).

Mężczyzna/kawaler niesprawny i „niewprawny” w miłości to nie tylko ktoś niezgrabny, niezręczny, łamaga, by nawiązać do przywołanych wyżej znaczeń, lecz ktoś trwale upośledzony i nieudolny jako kochanek. Z punktu widzenia pieśniowej bohaterki zasadne jest określenie kochanka-kaliki mianem osoby niepełnosprawnej lub wręcz osoby niesprawnej. Powodem tej jednoznacznej i stygmatyzującej kategoryzacji jest nie tylko niemożność zapewnienia dziewczynie / młodej żonie przyjemności erotycznych (niemożność kochania 'dotykania, poruszania'), ale też - co

13 Zob. Bartmiński 1974: 179. Por. też pieśń Ej, zobaczysz dziewucho (dokładnie z tym samym motywem) w książeczce Jadwigi Turowiczówny, zawierającej inscenizowane pieśni ludowe (TurPieś: 54-57).

14 Tak np. w pieśniach typu: Czego więcy chcesz, dziewucho, czego więcy chcesz? A czy to ja nie młody, czy ja ni mom urody; mom urodę, dziewucho, czego więcy chcesz (K 4 Kuj: 27 „od Strzelna”, Ludziska) oraz Zobaczysz-ci, kochaneczko, że cię Bóg skarze, da czy nam to tak nie ładnie obojgu w parze. Da czy to ja kalika? Czy ja nié mam wąsika? Co mnie nie lubisz (ibid. „od Lubrańca”, Paniewo). 
ważniejsze-niemożność spełnienia aktu miłosnego, któryw kulturze tradycyjnej właściwy jest nie tylko człowiekowi, ale całemu otaczającemu go kosmosowi.

\section{Skróty}

błrus. - białoruski; tur. - turecki; ukr. - ukraiński

\section{Literatura}

BARTMIŃSKI J., 1974, „Jaś koniki poił” (uwagi o stylu erotyku ludowego), „Teksty” nr 2, s. 11-24. BARTMIŃsKi J., 1981, Kwalifikacje gatunkowe a systematyka tekstów folkloru, [w:] W. Nawrocki, M. Waliński (red.), Literatura popularna, folklor, język, Katowice, s. 7-25.

BARTMIŃsKi J., 1990, Folklor - język - poetyka, Wrocław.

BARTMIŃski J., 1993, Ludowy styl artystyczny, [w:] idem (red.), Współczesny język polski, Encyklopedia kultury polskiej XX wieku, t. 2, Wrocław, s. 213-222.

Bartmiński J., Niebrzegowska-Bartmińska S., 2009, Tekstologia, Warszawa.

Bystroń J.S., 1921, Artyzm pieśni ludowej, Poznań.

Bystroń J.S., 1924, Pieśni ludu polskiego, Kraków.

Czernik S., 1962, Stare złoto. O polskiej pieśni ludowej, Warszawa.

Freud Z., 1987, Psychopatologia życia codziennego. Marzenia senne, Warszawa.

GalasińsKi D., 2013, Osoby niepełnosprawne czy osoby z niepełnosprawnością?, „Niepełnosprawność - zagadnienia, problemy, rozwiązania” nr IV, s. 3-6, [on-line:] https://www. pfron.org.pl/fileadmin/files/o/477_o1-Dariusz_Galasinski.pdf (dostęp: 24 V 2019).

Majer-Baranowska U., 1980, Kochać, [w:] J. Bartmiński (red.), Słownik ludowych stereotypów językowych. Zeszyt próbny, s. 83-118.

MoszyńsKi K., 1939, Kultura ludowa Słowian, cz. 2: Kultura duchowa, z. 2, Kraków.

Niebrzegowska S., 1996, Polski sennik ludowy, Lublin.

Niebrzegowska-Bartmińska S., 2012, Miejsce wartości w opisie gatunków mowy, [w:] A. Burzyńska-Kamieniecka (red.), Akty i gatunki mowy w perspektywie kulturowej, "Język a Kultura", t. 23, Wrocław, s. 33-41.

Niebrzegowska-BARTMiŃska S., 2013, Ustalanie znaczeń symbolicznych $w$ słowniku etnolingwistycznym, „LingVaria” nr 1 (15), s. 127-144.

NiebrZegowsKa-BARTMiŃskA S., 2015, Znaczenia symboliczne a wartości, [w:] J. Adamowski, M. Wójcicka (red.), Wartości w języku i kulturze, „Tradycja dla Współczesności. Ciągłość i Zmiana”, t. 8, Lublin, s. 47-64.

Pronok K., 2014, Gorzała lipka i jawor - lubelskie erotyki ludowe, [w:] J. Bartmiński, B. Maksymiuk-Pacek (red.), Lubelska pieśń ludowa na tle porównawczym, Lublin, s. 169-192.

Szymańska J., 1997, Przegląd repertuaru pieśni ludowych, [w:] L. Bielawski, A. Mioduchowska, Kaszuby, cz. 1: Pieśni obrzędowe, „Polska Pieśń i Muzyka Ludowa”, t. 2, Warszawa, s. $113-128$.

Tyrpa A., 2008, O eufemizmach w pieśniach ludowych, [w:] F. Czyżewski, A. Tyrpa (red.), Tabu językowe i eufemizacja $w$ dialektach słowiańskich, Lublin, s. 239-250.

Wężow ICZ-ZıóŁKowska D., 1991, Miłość ludowa. Wzory miłości wieśniaczej w polskiej pieśni ludowej XVIII-XX wieku, Wrocław. 


\section{Źródła i słowniki}

BartPANLub: J. Bartmiński (red.), Lubelskie, cz. 1: Pieśni i obrzędy doroczne, cz. 2: Pieśni i obrzędy rodzinne. Chrzciny, wesele, pogrzeb, cz. 3: Pieśni i teksty sytuacyjne, cz. 4: Pieśni powszechne, cz. 5: Pieśni stanowe i zawodowe, cz. 6: Muzyka instrumentalna. Instrumentarium - wykonawcy - repertuar, „Polska Pieśń i Muzyka Ludowa. Źródła i Materiały”, t. 4, Lublin 2011.

BıelKasz: L. Bielawski, A. Mioduchowska, Kaszuby, cz. 1: Pieśni obrzędowe, cz. 2: Pieśni powszechne, cz. 3: Pieśni powszechne i zawodowe, „Polska Pieśń i Muzyka Ludowa. Źródła i Materiały", t. 2, Warszawa 1998.

CHoDŚP: Z. Dołęga-Chodakowski, Śpiewy słowiańskie pod strzechą wiejską zebrane, opracował z rękopisu, wstępem i komentarzem opatrzył J. Maślanka, Warszawa 1973.

GąsMazur: Stoi lipa, lipuleczka. Pieśni mazurskie przez Józefa Gąsiorowskiego w 1884 zebrane, Warszawa 1976.

HerKal: C. Hernas, W kalinowym lesie, t. 2: Antologia polskiej pieśni ludowej ze zbiorów polskich XVIII w., Warszawa 1965.

K: O. Kolberg, Dzieła wszystkie:

K 1 Pieś: t. 1: Pieśni ludu polskiego, Kraków 1961 [wyd. fotoofset. z: Lud. Jego zwyczaje, sposób życia, mowa, podania, przysłowia, obrzędy, gusła, zabawy, pieśni, muzyka i tańce, przedstawił..., Serya I..., 1857].

K 2 SAn: t. 2: Sandomierskie, Kraków 1962 [wyd. fotoofset. z: Lud..., Serya I [2]..., 1865]. K 4 Kuj: t. 4: Kujawy, cz. 2, Kraków 1962 [wyd. fotoofset. z: Lud..., Serya IV..., 1867].

K 12 Poz: t. 12: W. Ks. Poznańskie, cz. 4, Kraków 1963 [wyd. fotoofset. z: Lud..., Serya XII..., 1879].

K 17 LuB: t. 17: Lubelskie, cz. 2, Kraków 1962 [wyd. fotoofset. z: Lud..., Serya XVII..., 1884].

K 18 KIEL: t. 18: Kieleckie, cz. 1, Kraków 1963 [wyd. fotoofset. z: Lud..., Serya XVIII..., 1885].

K 21 RAD: t. 21: Radomskie, cz. 2, Kraków 1964 [wyd. fotoofset. z: Lud..., Serya XXI..., 1888].

K 26 Maz: t. 26: Mazowsze, cz. 3, Kraków 1963 [wyd. fotoofset. z: Mazowsze. Obraz etnograficzny, skreślił..., t. 3: Mazowsze leśne, 1887].

K 27 Maz: t. 27: Mazowsze, cz. 4, Kraków 1964 [wyd. fotoofset. z: Mazowsze. Obraz..., t. 4: Mazowsze stare. Mazury. Kurpie, 1888].

K 28 MAz: t. 28: Mazowsze, cz. 5, Kraków 1964 [wyd. fotoofset. z: Mazowsze. Obraz..., t. 5: Mazowsze stare. Mazury. Podlasie, 1890].

K 44 GóR: t. 44: Góry i Podgórze, cz. 1, z rękopisów oprac. Z. Jasiewicz, D. Pawlak, red. E. Miller, Kraków 1968.

K 72/1 KuJ: t. 72/I: Kujawy. Suplement do tomów 3-4, z rękopisów i ze źródeł drukowanych zebr. i oprac. D. Pawlak, A. Skrukwa, Poznań 2009.

КотRzesz: F. Kotula, Hej, leluja, czyli o wygasajacych starodawnych pieśniach kolędniczych w Rzeszowskiem, Warszawa 1970.

KrzyżKuj: B. Krzyżaniak, A. Pawlak, J. Lisakowski, Kujawy, cz. 1: Teksty, „Polska Pieśń i Muzyka Ludowa. Źródła i Materiały”, t. 1, Kraków 1974.

KrzyżWiM: B. Krzyżaniak, A. Pawlak, Warmia i Mazury, cz. 1: Pieśni doroczne i weselne, cz. 2: Pieśni balladowe i społeczne, cz. 3: Pieśni zalotne i miłosne, cz. 4: Pieśni rodzinne 
i taneczne, cz. 5: Pieśni religijne i popularne, „Polska Pieśń i Muzyka Ludowa. Źródła i Materiały", t. 3, Warszawa 2002.

LL: A. Mioduchowska, L. Bielawski, Pieśni ludowe z Sieradzkiego i Łęczyckiego, „Literatura Ludowa. Wydawnictwo Polskiego Towarzystwa Ludoznawczego" 1962, nr 1-2, s. 38-58. PŁatKrak: Albośmy to jacy tacy. Zbiór pieśni Krakowiaków wschodnich i zachodnich, zebr. i oprac. P. Płatek, Kraków 1976.

PrzybJabє: Jabłoneczka. Antologia polskiej pieśni ludowej, ułożył J. Przyboś, wyd. II przejrz., Warszawa 1957.

RakPodh: M. Rak, Materiały do etnografii Podhala, „Biblioteka LingVariów”, t. 22, Kraków 2016.

SEBor: W. Boryś, Słownik etymologiczny języka polskiego, Kraków 2005.

SFPKrz: J. Krzyżanowski (red.), Słownik folkloru polskiego, Warszawa 1965.

SLSJ: J. Bartmiński (red.), Słownik ludowych stereotypów językowych. Zeszyt próbny, Wrocław 1980.

SSISL: J. Bartmiński, S. Niebrzegowska-Bartmińska (red.), Słownik stereotypów i symboli ludowych, t. I: Kosmos, z. 1: Niebo, światła niebieskie, ogień, kamienie, Lublin 1996, z. 2: Ziemia, woda, podziemie, Lublin 1999, z. 3: Meteorologia, Lublin 2012, z. 4: Świat, światło, metale, Lublin 2012, t. II: Rośliny, z. 1: Zboża, Lublin 2017, z. 2: Warzywa, przyprawy, rośliny przemysłowe, Lublin 2018.

StanTomKuj: L. Stankiewicz, W. Tomaszewski, Folklor muzyczny Kujaw Wschodnich w repertuarze kapeli „Spod Kowala”, Bydgoszcz 1985.

TN: Materiały terenowe z Pracowni „Archiwum Etnolingwistyczne” UMCS (po skrócie TN podano miejscowość i rok nagrania).

TuRPIEś: J. Turowiczówna, Inscenizowane pieśni ludowe, Warszawa 1933.

USJP: S. Dubisz (red.), Uniwersalny słownik języka polskiego, Warszawa 2003.

\section{A czy to ja kalika, czy nie mam konika? (lit. 'Am I a Cripple, or Don't I Have a Horse?'). Disability in the Light of Folk Erotic Poetry Summary}

Folk erotic poetry, as 'a song of lovers not yet tied by the knot', is a genre of text that relates the notion of love and the image of intimate body parts, the roles assigned to woman and to man, as well as social and moral norms in the traditional community. At the base of this genre lie such values as: happiness in love, physical contact, lovers' openness to the love game, youth and beauty, success and favour, the light-heartedness of the lovers, fun and laughter, freedom, faithfulness and stability; marriage is a relative value, important for the girl, and wealth. Another value that is important in the light of folk erotic poetry, is an able body, sexual performance; the anti-value is a body that is diabled, sick, deprived of its functionality. Deficiency in the art of love, the man's incompetence or inability to perform a sexual act is for the poetic lover a kind of disability that devalues and disqualifies him as a man and the partner of love act in the eyes of a woman awaiting sexual fulfillment. From the point of view of the heroine, it is justified to describe such a lover (love-cripple) as a disabled or even defunct person. The reason for this unambiguous and stigmatizing categorization is not only the inability to provide the girl (also a young wife by an old man) with erotic pleasure (kochanie 'touching, moving'), but also to perform the love act which the folk culture understands as a participation in the creative action of the entire cosmos. 